\title{
FACTORS INFLUENCING WILLINGNESS TO CONTRIBUTE FOR WAQF EDUCATION
}

\author{
Nurul Aien Binti Abd Aziz \\ Faculty Business Management, Universiti Teknologi MARA (UiTM), Johor. \\ (Email: nurul106.johor.uitm.edu.my) \\ Mohd Khairul Ariff Bin Noh ${ }^{2}$ \\ Faculty Business Management, Universiti Teknologi MARA (UiTM), Johor. \\ (Email: ariff890.johor.uitm.edu.my)
}

Received date: $20-05-2019$

Revised date: 25-07-2019

Accepted date: 09-08-2019

Published date: 15-09-2019

To cite this document: Abd Aziz, N. A., \& Noh, M. K. A. (2019). Factors Influencing Willingness to Contribute for Waqf Education. International Journal of Modern Education, 1(2), 41-47.

DOI: $10.35631 /$ ijmoe. 12004

\begin{abstract}
Nowadays, education has become more complex than before. The needs of knowledge, understanding, and passion among societies had caused an increase in education demand. To prepare a better and higher-level quality of education, the Ministry of Higher Education had played vital roles to enhance their services and efficiency levels. Nevertheless, the trend of budget allocation for operating expenditure in education sectors had shown a decline for the past three years, starting from the year 2016 until 2018 (Ministry of Higher Education, 2018). Since the budget allocation was cut off, public universities in Malaysia were encouraged to seek their own funds. One of the alternatives implemented by public universities was fund seeking through waqf collection. Through waqf, it assists public universities to support their needs especially for financial sustainability in the future. Respondents totaling 398 people comprising of various societies in Ipoh, Perak participated in this survey. Simple random sampling technique was employed to measure the social culture, understanding, awareness level, religiosity, marketing methods and willingness to contribute to Waqf education. Pearson correlation was used to measure the relationship between the variables. The results indicated insignificant relationships between awareness and willingness to contribute to waqf education. Furthermore, the findings also explained that the social culture, understanding, religiosity and marketing methods are the significant determinants in influencing the willingness to contribute to Waqf education. The findings from this study could benefit the Ministry of Higher Education itself, relevant government agencies and policymakers to promote Waqf as an alternative to generating income for education sectors in Malaysia.
\end{abstract}

Keywords: Waqf, Financial Sustainability, Higher Education, Contribute 


\section{Introduction}

Wakaf or Waqf in Arabic literally means to hold, to prevent or to restrain, while in shariah, waqf means voluntary, permanent, or irrevocable dedication of a portion of one's wealth - in cash or kind - to Allah. Once a waqf, it never gets gifted, inherited, or sold. It belongs to Allah and the corpus of the waqf always remains intact. The fruits of the waqf may be utilised for any shariah compliant purpose. "When a human being dies, his work for Allah comes to an end except for three things: a lasting charity, knowledge that benefit others, and a good child who calls on Allah for His favour" (Narrated by Muslim, Abu Daoud, At-Tirmidhi, and An-Nasaii). Basically the purpose of waqf is to protect a property to become the third party's own property. It brings the purpose of preventing a property from waqif (donor or founder) by dedicating an asset or property for the benefit of a defined group who has been pre-determined, pre-specified and stated by the waqif earlier on (as mentioned in the proof of waqf property or deed) and will be endowed from the beginning to the end in the name of Allah SWT and could not be taken back or owned by any individuals forever. In another note, waqf is an instrument or property that is used to provide benefits, and cannot be easily harmed or damaged even after many years of usage (Sabit, 2017).

From time to time, education is becoming more complexes particularly in higher learning institutions with a rising number of private institutions due to their demands and needs. The cost to enrol in a higher institution is not cheap, thus requiring students to fund their own studies through scholarships like Majlis Amanah Rakyat (MARA) or educational loans such as Perbadanan Tabung Pendidikan Tinggi Nasional (PTPTN). On top of that, the government has made an announcement during the 2017 Budget Allocation, whereby the government has reduced the Operating Expenditure with 19.23\% aggregate (Malaysia Budget, 2016).

Since the budget allocation has been cut off, development programmes that capable to help develop the students to strive ahead and beyond their capabilities also need to be reduced. Hence, this causes the institutions to have and find their own financial allocations in order to exercise better educational processes. Even though poverty is a universal problem; one of the contributing factors of poverty is the lack of education. The lack of education and poverty have a cause-effect relationship, since the lack of education leads to low level of human capital and capacity (Hassan, 2006). By initiating the waqf principle through education system, it aims at providing support services to reduce disparity and inequality among social strata. Besides that, preservation of knowledge is among one tenet in Maqasid Shariah and thus it becomes an obligation for Muslims to uphold the notion by initiating the waqf for higher learning institutions. In western countries, waqf is termed as endowment, foundation or trust. It has been successfully being practiced by some renowned universities such as Al-Azhar, Cambridge and Harvard through the use of cash and land contribution (Hassan, Rahman, \& Yazid, 2013)

\section{Research Objective}

The main research objective for this study is to examine the relationship between social culture, understanding, awareness level, religiosity, marketing methods and willingness to contribute to Waqf education.

\section{Problem Statement}

Nowadays, education has becoming more complex than before. The need to have knowledge, understanding and passion in the particular sectors has causing an increasing in the number of demand. In 2017, the government has announced the budget allocation for education sector had reducing with aggregate of 19.23\% (Malaysia Budget, 2017). Since the budget allocation has been cut off, the development program that is capable to assist in developing the student also 
need to be reduced. Hence, this causing the institution needs to generate and seeking for their own financial allocation in order sustain their financial especially in future.

Moreover, the background of student also causing them to seeking for scholarship and educational loan for surviving their life and education at university. In current situation, the increasing in cost of living had require them to seeking for additional financial aid (Wan Ahmad, , Abdul Wahab, \& Shaharuddin, 2014) .Due to this, government had come out with initiative to introduce and implement the waqf as a strategies for fund collection and funding the higher learning institutions. In Malaysia education blueprint (2015-2025), Ministry of Higher Education had developing and outlining a waqf model as a guidance for higher education institution in a way to develop their own waqf fund. Hence, this study is aims to investigate the factors behind the willingness of society to contribute for waqf education.

\section{Literature Review}

Locked in 1689 had mentioned knowledge as a perception of the agreement or disagreement of two ideas. In another note, Peter F.Drucker described knowledge as information that changes something or somebody either by becoming grounds for actions or by making an individual or an institution capable of making difference and effective actions. According to Ridhwan, Aziz, \& Yusof (2014) described that three reasons contributing to low level Islamic financial planning including waqf practices are; misconception towards instruments, reluctance despite the knowledge of Islamic financial instruments, and affordability to participate. According to a research done by Ismail (2015),only $40 \%$ of their respondents had knowledge about cash waqf. The three elements of knowledge that should be taken into consideration on knowledge of waqf include the institutions, and processes of collection and distribution. However, a study carried out by Echchabi, Eddine, \& Ayedh (2013 found that waqf knowledge among Malaysian university students is good.

In term of awareness, the majority of Muslims in Malaysia is aware that waqf is used to assist the poor and the needy (Dahlia \& Haslindar, 2013).However, a study by Mohd Puad, Jamlus Rafdi, \& Shahar (2014) found that most people believe that waqf can only being contributed by Muslims but not to non-Muslims. Furthermore, the Muslim society still does not realize the importance of waqf for economic development due to the lack of information being promoted. In a study conducted by Karim \& Murad (2002) who studied the practice of waqf estate in Bangladesh, he found that the majority of the people have commonly assumed that the waqf instruments are only limited to building mosques, schools and other religious buildings and facilities. It indicates that waqf instruments are commonly known for religiously-based purposes rather than broadening the scope to socially-based purposes.

In analysing the pattern of authorship related to Islamic wealth planning including waqf, Ridhwan et al (2014) described the low level of awareness and knowledge being one of the factors contributing to the reason why Islamic financial planning is not widely practiced. In addition to that Budiman (2017) in an attempt to raise awareness of waqf as a poverty alleviation tool concluded that the lack of awareness on waqf is a barrier to harness waqf potential. It is supported by Faiz (2014) and Ibrahim (2013), who said that there are still a lack of awareness to contribute to waqf among the society. They also remarked that the lack of promotion about waqf contribution and practice may have a huge implication for the requisite awareness needed to leverage the socio-economic potential of waqf as an Islamic social finance 
option. A more effective and creative method of delivering information can be used as the access of mass information has a positive relationship on willingness of the society to contributing to educational waqf (Marlina \& Anggi Wahyu, 2016). As being mentioned by Adeyemi, Ismail, \& Hassan (2016), the level of understanding towards educational waqf has a positive relationship affecting the willingness of the societies to contribute to waqf. As suggested by Shukor et al (2018), religiosity in Muslims contributes a significant factor to determine a positive attitude towards cash waqf. It shows that religious obligation has influenced the Muslims to contribute to waqf and repeatedly contribute again for cash waqf.

\section{Research Methodology}

This study is a descriptive research employing the survey method through the distribution of questionnaires. Questionnaires were personally administered to ensure a high response rate. Simple random sampling was used, with a total number of 398 respondents, comprising of individuals from areas in Perak, who participated in this survey. Besides descriptive statistics, Pearson Correlation was also employed to establish the relationship between the variables. Cronbach's Alpha was also tested for reliability and validity; whereby the result for Cronbach's Alpha for the overall questions is above 0.8 indicating that it is acceptable.

\section{Theoretical Framework}

The theoretical framework as follows:

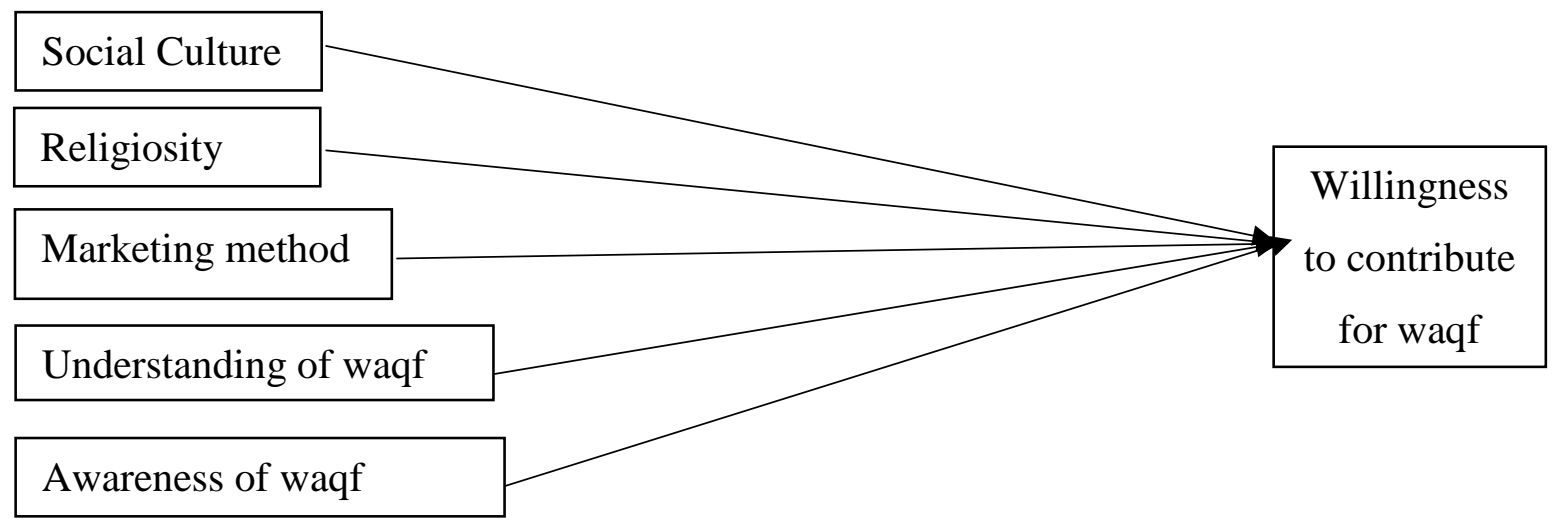

Independent variable

Dependent variable

\section{Research Findings}

Correlation Analysis

Table 1: Correlations Analysis

\begin{tabular}{|c|c|c|c|c|c|c|}
\hline Variables & 1 & 2 & 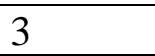 & 4 & 5 & 6 \\
\hline 1. Social culture & - & & & & & \\
\hline $\begin{array}{l}\text { 2. Understanding } \\
\text { of Waqf }\end{array}$ & $0.481 * *$ & & & & & \\
\hline $\begin{array}{l}\text { 3. Awareness of } \\
\text { Waqf }\end{array}$ & $0.350 * *$ & $0.600 * *$ & & & & \\
\hline 4. Religiosity & $0.346 * *$ & $0.441 * *$ & $0.431 * *$ & & & \\
\hline
\end{tabular}



5. Marketing method
6. Willingness to contribute
$0.564 * *$
$0.625 * *$
$0.294 * *$

*** Significance level $=0.01$
Dependent variable: Willingness to contribute

Correlation is used to understand the relationships between two continuous variables and show the strength, direction as well as the significance of the bivariate relationship of the variables that is measured at an interval or ratio level Kaliani et al. (2016). Referring to table 1, there is a positive and moderate correlation between social culture and willingness to contribute for waqf education $(\mathrm{p}=0.540$, significance level $=0.01)$. The understanding of waqf has a moderate and positive correlation with the willingness to contribute for waqf education $(p=0.481)$.Next, the awareness of waqf had shown the low correlation with the willingness to contribute for waqf education $(\mathrm{p}=0.350)$.For the religiosity and marketing method also shown a moderate and significant relationship towards the willingness to contribute for waqf education (marketing method $=0.206$ and religiosity: $\mathrm{p}=0.206$ ).

Table 2: Multiple Regression Analysis

\begin{tabular}{|l|l|l|l|c|c|}
\hline \multicolumn{1}{|c|}{ Model } & $\begin{array}{c}\text { Unstandardized } \\
\text { Coefficients }\end{array}$ & $\begin{array}{c}\text { Unstandardized } \\
\text { Coefficients }\end{array}$ & $\begin{array}{l}\text { Standardized } \\
\text { Coefficients }\end{array}$ & t & Sig \\
\cline { 2 - 5 } & \multicolumn{1}{|c|}{ B } & \multicolumn{1}{|c|}{ Std Error } & & & \\
\hline Constant & 0.965 & 0.245 & & 3.945 & 0.000 \\
\hline Social Culture & 0.404 & 0.045 & 0.426 & 8.914 & 0.000 \\
\hline $\begin{array}{l}\text { Understanding } \\
\text { on Waqf }\end{array}$ & 0.343 & 0.061 & 0.301 & 5.616 & 0.000 \\
\hline Awareness & 0.29 & 0.059 & 0.027 & 0.493 & 0.623 \\
\hline Religiosity & 0.250 & 0.057 & 0.195 & 4.374 & 0.000 \\
\hline $\begin{array}{l}\text { Marketing } \\
\text { method }\end{array}$ & 0.267 & 0.058 & 0.246 & 4.645 & 0.000 \\
\hline
\end{tabular}

Dependent variable: Willingness to contribute

Regression analysis of coefficient is used to test the coefficient between the independent and dependent variables (Kaliani et al., 2016) .The result from table 2 shows the beta value for social culture is 0.404 followed by understanding of waqf $(0.343)$, awareness $(0.29)$, religiosity (0.250) and marketing method (0.267).The result suggest that social culture has the highest impact on the willingness to contribute for waqf education. In addition to this, only four variables social culture $(\mathrm{p}=0.000)$, understanding on waqf $(\mathrm{p}=0.000)$, religiosity $(\mathrm{p}=0.000)$ and marketing method $(\mathrm{p}=0.000)$ are significant predictor to willingness to contribute for waqf education. The other variable which is awareness $(p=0.623)$ is not predictor to willingness to contribute for waqf education

\section{Conclusion and Implications of Study}

The findings of this study showed that all four dimensions (social culture, understanding on waqf, religiosity and marketing method) can be used to predict the willingness to contribute to waqf education among the societies. Several implications can be derived from this study. 
Firstly, this study is significant for those in the society themselves, like the management of waqf. This group of individuals will have the benefits to understand better on how, why, who and when to explain (promote) to the others in the society such as the contributors and those who receive the benefits. Furthermore, this study is significant for those in the society themselves, like the contributors of waqf. This group of individuals are the ones who donate their money, shares, or properties in the path to gain rewards in the hereafter life. These individuals need to have a better understanding to lead them to enhance their efforts to contribute more to waqf. Nevertheless, this study is significant for those in the society, namely the receiver of benefits of waqf. This group of individuals will enjoy the benefits of waqf donated or contributed by the contributors of waqf. Therefore, the individuals need to understand better so that the benefits they gained will not end up only for them, but also for the others in the society, like the next generation too.

\section{References}

Adeyemi, A. A., Ismail, N. A., \& Hassan, S. S. B. (2016). An Empirical Investigation of the Determinants of Cash Waqf Awareness in Malaysia, 4878, 501-520.

Budiman, M. A. (2017). The Significance of Waqf for Economic Development.

Dahlia, I., \& Haslindar, I. (2013). Revival of Waqf Properties in Malaysia. Sustainable Development Through The Islamic Economics System.

Echchabi, A., Eddine, C. O. H., \& Ayedh, A. M. (2013). Awareness about Waqf among Algerian Students : An Exploratory Study, 1-14.

Faiz, O. A. (2014). An Analysis of Cash Waqf Participation among Young Intellectuals. 13 April 2014, Istanbul 9th International Academic Conference.

Hassan, M. K. (2006). The Role of Zakat in Poverty Alleviation in Bangladesh", Paper Presented at a conference in Dhaka, November 24-26, 2006.

Hassan, N., Rahman, A. A., \& Yazid, Z. (2013). Pengurusan dan pembangunan wakaf pendidikan : kajian kes di selangor, malaysia the management and development of waqfs for education : case study in selangor, malaysia, 386-406.

Ibrahim, H. (2013). Revival of waqf properties in malaysia , 4-5.

Ismail, W. M. W. (2015). Awareness of Cash Waqf among the Malaysian Muslims. In 1st International Islamic Heritage Conference (ISHEC) 2015 (pp. 11-12).

Kaliani, V. P., Chandran, V. G. ., G., A., S. B., N., Othman, A. A., \& Thirunavukkarasu, K. (2016). Research Methodology Tools, Methods and Techniques. Petaling Jaya: Malaysia Logistics and Supply Chain Association (MLSCA).

Karim, M. F., \& Murad, M. W. (2002). An Analysis of Disbursement of Waqf Funds and their Potential in Bangladesh. Journal of Islamic Economics, Banking and Finance, 6(4), 87106.

Malaysia, M. Of F. (2016). 2016 Budget Ministry Of Finance Malaysia.

Marlina, E., \& Anggi Wahyu, M. (2016). Wakaf Uang: Tingkat Pemahaman Masyarakat \& Faktor Penentunya (Studi Masyarakat Muslim Kota Surabaya, Indonesia (pp. 1-28).

Mohd Puad, B. N. A., Jamlus Rafdi, N. B., \& Shahar, W. S. S. B. (2014). Issues and Challenges of Waqf Instruments: A Case Study in MAIS. E-Proceedings of the Conference on Management and Muamalah, (May), 978-983. Https://doi.org/10.1007/s13398-0140173-7.2

Ridhwan, M., Aziz, A., \& Yusof, M. A. (2014). An Initial Study on Student' s Need towards Islamic Waqf Bank for Education, (1992), 71-74.

Sabit, M. T. (2017). Sustaining the Means of Sustainability: The Need for Accepting Wakaf ( Waqf ) Assets in Malaysian Property Market sustaining the means of sustainability: the need for accepting, (January 2008) 
Shukor, S. A., Johari, F., Wahab, K. A., Zulkefli, Z. K., Alias, M. H., Rahman, A. A., Wahab, K. A. (2018). Trust on awqaf institutions: evidence from Malaysia. Https://doi.org/10.1108/JIMA-05-2017-0054

Wan Ahmad, W. A. Bin, Othman@Seman, M. M. Bin, Abdul Wahab, M. H. Bin, \& Shaharuddin, N. B. (2014). Pembangunan Waqaf Pendidikan Di Ipt Malaysia: Satu Alternatif Untuk Mengurangkan Kos Pengajian. 